\title{
Concurrence of chromosome 3 and 4 aberrations in human uveal melanoma
}

\author{
EVA SIPOS ${ }^{1}$, KATA HEGYI $^{2}$, ANDREA TRESZL $^{1 *}$, ZITA STEIBER $^{3}$, GABOR MEHES $^{2}$, \\ NIKOLETTA DOBOS ${ }^{1}$, KLARA FODOR $^{1}$, GABOR OLAH $^{1}$, LORANT SZEKVOLGYI ${ }^{4}$, \\ ANDREW V. SCHALLY ${ }^{5-8}$ and GABOR HALMOS ${ }^{1,5}$ \\ Departments of ${ }^{1}$ Biopharmacy, ${ }^{2}$ Pathology and ${ }^{3}$ Ophthalmology, University of Debrecen; \\ ${ }^{4}$ MTA-DE Momentum, Genome Architecture and Recombination Research Group, \\ Research Centre for Molecular Medicine; Department of Biochemistry and Molecular Biology, \\ University of Debrecen, 4032 Debrecen, Hungary; ${ }^{5}$ Endocrine, Polypeptide and Cancer Institute and \\ South Florida VA Foundation for Research and Education, Veterans Affairs Medical Center, Miami, FL 33125; \\ ${ }^{6}$ Department of Pathology, Miller School of Medicine, University of Miami; ${ }^{7}$ Department of Medicine, \\ Divisions of Hematology-Oncology and Endocrinology, Miller School of Medicine, University of Miami, \\ Miami, FL 33101; ${ }^{8}$ Sylvester Comprehensive Cancer Center, University of Miami, Miami, FL 33136, USA
}

Received August 4, 2016; Accepted February 10, 2017

DOI: $10.3892 / o r .2017 .5496$

\begin{abstract}
Uveal melanoma (UM) is the most common primary intraocular malignancy with a very poor prognosis. The most frequent chromosome aberration in UM is the monosomy of chromosome 3. Previously, we demonstrated that $\sim 50 \%$ of UMs express type-I receptor for luteinizing hormone-releasing hormone (LH-RH-R). The gene encoding LH-RH-R is located in chromosome 4 (location: 4q21.2); however, the occurrence of numerical aberrations of chromosome 4 have never been studied in UM. In the present study, we investigated the abnormalities of chromosome 3 and 4, and the possible correlation between them, as well as with LH-RH-R expression. Forty-six specimens of UM were obtained after enucleation. Numerical aberrations of chromosome 3 and 4 were studied by fluorescence in situ hybridization (FISH). Chromosome 4 was detected in normal biparental disomy only in $14(30 \%)$ samples; however, 32 cases (70\%) showed more than 2 signals/nucleus. Monosomy of chromosome 3 could be found in $16(35 \%)$ samples. In 6 specimens $(13 \%)$, more than 2 copies of chromosome 3 were found, while normal biparental disomy was detected in 24 (52\%) samples. Statistical analysis indicated a statistically significant $(\mathrm{p}<0.05)$ correlation between the copy number of chromosome 3 and 4 . Moreover, moderate difference was revealed in the survival rate of the
\end{abstract}

Correspondence to: Dr Gabor Halmos, Department of Biopharmacy, University of Debrecen, Nagyerdei Krt 98, 4032 Debrecen, Hungary E-mail: halmos.gabor@pharm.unideb.hu

\section{"Deceased}

Key words: human uveal melanoma, aberrations of chromosome 3 and 4 , chromosome index, luteinizing hormone-releasing hormone receptor, fluorescence in situ hybridization
UM patients with various pathological profiles. No correlation was found between chromosome aberrations and LH-RH-R expression. Our results clearly demonstrate abnormalities in chromosome 3 and 4 and the incidence of the monosomy of chromosome 3 in human UM. In summary, our results provide new incite concerning the genetic background of this tumor. Our findings could contribute to a more precise determination of the prognosis of human UM and to the development of new therapeutic approaches to this malignancy.

\section{Introduction}

Uveal melanoma (UM) is the most frequently occurring primary intraocular tumor in adults, and is associated with significant mortality (1). Several histologic prognostic factors have been described for this type of cancer, such as large tumor diameter (LTD), location at onset, age at time of diagnosis, presence of epitheloid cells and involvement of the ciliary body (2). The cause of UM is unknown, but several risk factors have been associated with the development of the disease such as light irides, uveal naevi, dysplastic naevus syndrome and oculodermal melanocytosis. UM most commonly affects Caucasian males. Despite the early diagnosis, the mortality due to UM has remained relatively unchanged. Specific genetic alterations can predict the development of metastasis and survival in patients with UM. Monosomy 3 strongly predicts metastatic risk and other chromosomal abnormalities, also correlated with metastatic diseases $(3,4)$. Approximately half of the patients develop metastases, most frequently in the liver $(5,6)$. Monosomy 3 correlates with epitheloid histology, ciliary body involvement and poor outcome (6). Lack of chromosome 3 has been demonstrated in 5-10\% of all the patients, and the remaining copy is duplicated (7). Occasionally, partial deletions of chromosome 3 have been detected and a common region of allelic loss on 3p25 and on 3q24-q26 
could be defined. Most likely these regions harbor putative tumor-suppressor genes, but no specific genes have yet been identified (7). Monosomy 3 is present in 50-60\% of tumors, which is associated with isochromosome $8 \mathrm{q}$ and high level of $8 \mathrm{q}$ gain (8). The common region of amplification was found to range from $8 \mathrm{q} 24.1$ to $8 \mathrm{q} 24.3$. A potential metastasis-suppressor gene, LZTS1, is located in 8p21 (9). In UM, other recurrent chromosome alterations, such as lack of $1 \mathrm{p}$ and $16 \mathrm{q}$, have been described (10). One of the suggested tumor-suppressor genes, APITD1, in the $1 \mathrm{p} 36$ region was shown to be negligible for survival rate and the common deleted regions on chromosome 1 were found to range from $1 \mathrm{p} 34.3$ to 36.2 (10). Infrequently, abnormalities of other chromosomes such as gain of $6 \mathrm{p}$, loss of $6 q$, loss of 9p, loss of chromosome 10, loss of 11q23-q25, and gain of chromosomes 7 and 10 have been reported (11). UM can be classified into 2 groups based on the status of chromosome 3: class 1 tumors with 2 copies, and class 2 tumors, with monosomy of chromosome 3 . The characteristics of these tumors basically differ; class 1 tumors have been characterized by gain of $6 \mathrm{p}$ and $8 \mathrm{q}$ while class 2 tumors by monosomy 3 and gain of entire 8q (12). Class 1 tumors exhibit low aneuploidy, and patients rarely have metastases whereas class 2 tumors have a higher chance of aneuploidy and patients have a high risk to develop metastases (13). Hypothalamic luteinizing hormone-releasing hormone (LH-RH) is the primary link between the hypothalamus and the pituitary gland in the regulation of gonadal functions and has a pivotal role in vertebrate reproduction (14). The effects of LH-RH and its analogs are mediated by high-affinity G-protein-coupled receptors located on the membranes of the pituitary gonadotrophs and several cancer cells (15-17). Tumoral receptors for LH-RH have been detected on human breast, prostatic, ovarian, endometrial and pancreatic cancers and in human melanomas, non-Hodgkin's lymphomas and renal cell carcinomas (14-20). Over the past decade, a direct receptor-mediated antiproliferative effect of LH-RH-analogs on tumor cells was proposed $(14,16,17,19-21)$. The receptors for LH-RH (LH-RH-R) on human tumors can also serve as targets for LH-RH analogs linked to various cytotoxic agents $(15-17,22,23)$. In our previous study, it was demonstrated that a high percentage $(47 \%)$ of human UMs express the type-I receptor for LH-RH (24). The gene encoding LH-RH-R is located on chromosome $4 \mathrm{q} 21.2$; however, the numerical aberrations of chromosome 4 have never been studied in UM.

In the present study, we aimed to investigate the copy number of chromosome 3 , particularly the monosomy of chromosome 3 which has been extensively described in the aggressive behavior of UM, and chromosome 4 in 46 human UM specimens using fluorescence in situ hybridization (FISH). Furthermore, chromosome index (CI) and 'dominant' cell population values for chromosome 3 and 4 were determined. Additionally, we analyzed the survival rate of the UM patients according to their CI. The correlation between LH-RH-R expression and the copy number of chromosome 3 and 4 was also investigated.

\section{Materials and methods}

Human UM tissues. Specimens of human UM were obtained from 46 patients $30-84$ years of age at the time of enucleation at the Department of Ophthalmology of the University of Debrecen, Debrecen, Hungary. Normal lymphocyte samples, used as positive controls, were collected at the Department of Pathology of the University of Debrecen. Informed consent was obtained before enucleation, and the present study was performed according to the tenets of the Declaration of Helsinki and the Local Institutional Ethics Committee. Fresh tumor tissue was obtained within $1 \mathrm{~h}$ after enucleation, according to a standardized protocol. Briefly, an incision was made through the tumor, leaving the optic nerve intact. The quantity of tissue obtained $\left(5-8 \mathrm{~mm}^{3}\right)$ depended on the size of the tumor. A sample was taken from the side opposite the optic nerve and selected portions of the melanoma tissues were flash frozen and stored at $-80^{\circ} \mathrm{C}$. Conventional histopathologic examination was performed on all tumors and the origin of the tumor was confirmed. Follow-up data from the time of diagnosis until the end of the study were obtained by reviewing the charts of the patients (whether we had the availability) and/or by contacting their general physicians. The clinicopathological data of the 46 patients are summarized in Table I. UM samples were divided into 4 groups based on the CI: NN (normal CI3 and CI4), NP (normal CI3 pathological CI4), PN (pathological CI3 and normal CI4) and PP (pathological CI3 and CI4). To simplify the evaluation, 2 major groups were also created: $\mathrm{N}$ (including $\mathrm{NN}$ ) and $\mathrm{P}$ (containing $\mathrm{NP}, \mathrm{PN}$ and $\mathrm{PP}$ ).

Touch preparations. The tumor tissues were transferred from -80 to $-20^{\circ} \mathrm{C}$. The tissue samples were used for touch preparations, which were obtained by pressing frozen tissue samples several times on the surface of a silanized slide. The slides were fixed in methanol:acetic acid (3:1), air dried, washed with $70 \%$ acetic acid solution and distilled water, dehydrated with 70,80 and $90 \%$ ethanol and air dried. The slides were stored at $-20^{\circ} \mathrm{C}$ until further use.

\section{FISH}

DNA FISH probes. Numerical aberrations of chromosome 3 and 4 were studied by FISH with centromere-specific probes (CEP; Chromosome Enumeration DNA FISH Probes, Vysis, Germany). The probes consisted of chromosome 3- or 4-specific tandem-repeat DNA sequences. The CEP probes were directly labeled with SpectrumOrange (chromosome 3) and SpectrumGreen (chromosome 4) fluorophores. The centromeric probes contain $7 \mu \mathrm{l}$ CEP hybridization buffer, $1 \mu \mathrm{l}$ probe and $1 \mu \mathrm{l}$ distilled water.

FISH hybridization. FISH was carried out according to a general protocol with some modifications (25). The slides containing the touch preparations were fixed in methanol:acetic acid (3:1) at $-20^{\circ} \mathrm{C}$, and then incubated in $15 \mu 110 \%$ pepsin in $100 \mu \mathrm{l} 1 \mathrm{M} \mathrm{HCl}$. The slides were washed with $1 \mathrm{X}$ PBS buffer, and then dehydrated in 70,85 and 100\% alcohol series and air dried. DNA FISH probe was added, coverslips were applied and sealed to the slide with rubber cement. The slides were denatured at $75^{\circ} \mathrm{C}$ for $5 \mathrm{~min}$ and hybridized overnight at $42^{\circ} \mathrm{C}$. After hybridization, the slides were washed with $50 \%$ formamide $/ 2 \mathrm{X}$ standard saline citrate (SSC) solution at $42^{\circ} \mathrm{C}$ for $7 \mathrm{~min}$, and then with $2 \mathrm{X} \mathrm{SSC}$ solution at $42^{\circ} \mathrm{C}$ for $7 \mathrm{~min}$. The slides were then counterstained with 4',6-diamidino-2-phenylindole (DAPI) in anti-fade solution (Fig. 1). 
Table I. Clinicopathological characteristics, chromosome index (CI) results and survival data of the 46 uveal melanoma patients.

\begin{tabular}{|c|c|c|c|c|c|c|c|c|c|}
\hline $\begin{array}{l}\text { Sample } \\
\text { ID }\end{array}$ & Gender & $\begin{array}{c}\text { Age } \\
\text { (years) }\end{array}$ & Type & Eye & Localization & Survival & $\mathrm{CI} 3$ & CI4 & $\begin{array}{c}\text { Postoperative } \\
\text { days }\end{array}$ \\
\hline 1 & $\mathrm{~F}$ & 79 & ND & $\mathrm{L}$ & $\mathrm{C}$ & Deceased & 1.43 & 2.72 & 210 \\
\hline 2 & M & 76 & Spindle & $\mathrm{L}$ & $\mathrm{P}$ & Alive & 2.00 & 2.65 & 1,559 \\
\hline 3 & $\mathrm{~F}$ & 44 & Spindle-B & $\mathrm{L}$ & Inferior temporal: $\mathrm{P}$ & Alive & 2.19 & 3.39 & 1,770 \\
\hline 4 & $\mathrm{~F}$ & 50 & Spindle & $\mathrm{R}$ & Temporal: P & Alive & 2.41 & 3.00 & 1,497 \\
\hline 5 & M & 76 & Spindle & $\mathrm{R}$ & $\mathrm{P}$ & Deceased (liver) & 2.18 & 3.94 & 620 \\
\hline 6 & $\mathrm{~F}$ & 30 & Spindle-A & $\mathrm{L}$ & $\mathrm{P}$ & Alive & 2.17 & 3.34 & 1,770 \\
\hline 7 & M & 66 & Epithelioid & $\mathrm{L}$ & Temporal: $\mathrm{P}$ & Alive & 2.04 & 4.01 & 333 \\
\hline 8 & M & 61 & Spindle-B & $\mathrm{L}$ & Temporal: $\mathrm{P}$ & Alive & 2.21 & 2.81 & 1,505 \\
\hline 9 & M & 53 & ND & $\mathrm{L}$ & Superior temporal: $\mathrm{P}$ & Alive & 2.04 & 3.94 & 1,260 \\
\hline 10 & M & 53 & Epithelioid & $\mathrm{R}$ & $\mathrm{P}$ & Alive & 1.48 & 2.79 & 1,442 \\
\hline 11 & $\mathrm{~F}$ & 79 & Epithelioid & $\mathrm{R}$ & $\mathrm{P}$ & Dead & 2.07 & 3.43 & 548 \\
\hline 12 & M & 67 & Epithelioid & $\mathrm{L}$ & $\mathrm{P}$ & Alive & 2.10 & 2.53 & 1,630 \\
\hline 13 & $\mathrm{~F}$ & 72 & Epithelioid & $\mathrm{L}$ & Temporal: P & Deceased (liver) & 1.37 & 5.39 & 317 \\
\hline 14 & M & 35 & Spindle & $\mathrm{L}$ & Superior nasal: $\mathrm{P}$ & Alive & 1.71 & 2.94 & 740 \\
\hline 15 & M & 55 & Spindle-B & $\mathrm{L}$ & $\mathrm{P}$ & Alive & 2.68 & 3.03 & 1,545 \\
\hline 16 & M & 65 & Spindle-B & $\mathrm{R}$ & Anterior temporal: $\mathrm{P}$ & Dead & 2.53 & 1.91 & 467 \\
\hline 17 & $\mathrm{~F}$ & 68 & Spindle & $\mathrm{L}$ & $\mathrm{P}$ & Alive & 2.07 & 1.75 & 1,702 \\
\hline 18 & M & 71 & Spindle-B & $\mathrm{R}$ & $\mathrm{P}$ & Alive & 2.28 & 3.43 & 1,006 \\
\hline 19 & M & 69 & Mixed & $\mathrm{R}$ & Anterior nasal: $\mathrm{P}$ & Alive & 1.37 & 2.31 & 958 \\
\hline 20 & M & 64 & ND & $\mathrm{L}$ & Temporal: $\mathrm{P}$ & Deceased (bone) & 1.79 & 2.39 & 312 \\
\hline 21 & $\mathrm{~F}$ & 75 & Epithelioid & $\mathrm{L}$ & Temporal: $\mathrm{P}$ & Alive & 2.26 & 3.04 & 846 \\
\hline 22 & $\mathrm{~F}$ & 79 & ND & $\mathrm{R}$ & $\mathrm{C}$ & Alive & 2.43 & 2.36 & 1,442 \\
\hline 23 & $\mathrm{~F}$ & 75 & Mixed & $\mathrm{L}$ & Anterior nasal: P & Alive & 1.06 & 1.94 & 1,902 \\
\hline 24 & M & 70 & Mixed & $\mathrm{R}$ & $\mathrm{P}$ & Alive & 1.99 & 2.06 & 1,022 \\
\hline 25 & M & 47 & Epithelioid & $\mathrm{L}$ & $\mathrm{C}$ & Deceased (liver) & 1.53 & 2.08 & 832 \\
\hline 26 & M & 42 & Epithelioid & $\mathrm{R}$ & $\mathrm{P}$ & Alive & 2.05 & 2.48 & 947 \\
\hline 27 & M & 72 & Epithelioid & $\mathrm{L}$ & $\mathrm{P}$ & Alive & 1.97 & 2.48 & 932 \\
\hline 28 & $\mathrm{~F}$ & 68 & Epithelioid & $\mathrm{L}$ & Juxtapapillary & Alive & 1.87 & 221 & 965 \\
\hline 29 & M & 72 & Epithelioid & $\mathrm{L}$ & $\mathrm{P}$ & Deceased (liver) & 1.88 & 2.27 & 29 \\
\hline 30 & M & 64 & Spindle & $\mathrm{L}$ & Anterior retinal: $\mathrm{P}$ & Alive & 1.23 & 2.22 & 2,021 \\
\hline 31 & M & 42 & Epithelioid & $\mathrm{R}$ & $\mathrm{P}$ & Deceased (orbita) & 2.01 & 2.82 & 303 \\
\hline 32 & $\mathrm{~F}$ & 68 & Epithelioid & $\mathrm{R}$ & $\mathrm{P}$ & Deceased (liver/lung) & 1.66 & 2.55 & 439 \\
\hline 33 & M & 51 & Spindle-B & $\mathrm{L}$ & $\mathrm{C}$ & Alive & 0.94 & 2.14 & 1,609 \\
\hline 34 & $\mathrm{~F}$ & 50 & Spindle-B & $\mathrm{R}$ & Juxtapapillary & Alive & 2.22 & 2.50 & 1,097 \\
\hline 35 & M & 56 & ND & $\mathrm{L}$ & Anterior temporal: $\mathrm{P}$ & Alive & 1.33 & 2.37 & 648 \\
\hline 36 & $\mathrm{~F}$ & 55 & Epithelioid & $\mathrm{L}$ & Anterior & Alive & 2.07 & 2.04 & 623 \\
\hline 37 & $\mathrm{~F}$ & 83 & Spindle-A & $\mathrm{R}$ & nasal: $\mathrm{P}$ & Deceased (liver) & 1.40 & 1.80 & 261 \\
\hline 38 & $\mathrm{~F}$ & 63 & Spindle-A & $\mathrm{R}$ & $\mathrm{C}$ & Alive & 1.31 & 2.10 & 490 \\
\hline 39 & M & 70 & Spindle-B & $\mathrm{R}$ & Temporal: P & Alive & 1.17 & 2.33 & 950 \\
\hline 40 & $\mathrm{~F}$ & 61 & Spindle & $\mathrm{L}$ & $\mathrm{P}$ & Alive & 1.88 & 2.04 & 740 \\
\hline 41 & M & 70 & Epithelioid & $\mathrm{L}$ & $\mathrm{P}$ & Alive & 1.41 & 1.81 & 524 \\
\hline 42 & $\mathrm{~F}$ & 70 & Epithelioid & $\mathrm{R}$ & $\mathrm{P}$ & Alive & 1.35 & 2.26 & 582 \\
\hline 43 & $\mathrm{~F}$ & 71 & Mix & $\mathrm{R}$ & Anterior & Alive & 1.76 & 2.28 & 559 \\
\hline 44 & $\mathrm{~F}$ & 52 & Mix & $\mathrm{R}$ & Temporal: P & Alive & 1.93 & 2.52 & 560 \\
\hline 45 & $\mathrm{~F}$ & ND & Spindle & $\mathrm{L}$ & $\mathrm{C}$ & Alive & 1.93 & 2.99 & 592 \\
\hline 46 & $\mathrm{~F}$ & 54 & Spindle & $\mathrm{R}$ & Anterior temporal: $\mathrm{P}$ & Alive & 1.84 & 1.91 & 613 \\
\hline
\end{tabular}

CI3, chromosome index 3; CI4, chromosome index 4; F, female; M, male; ND, no data; L, left; R, right; C, corpus ciliare; P, posterior pole. In the survival column, the cause of death (metastasis) is mentioned in brackets. 


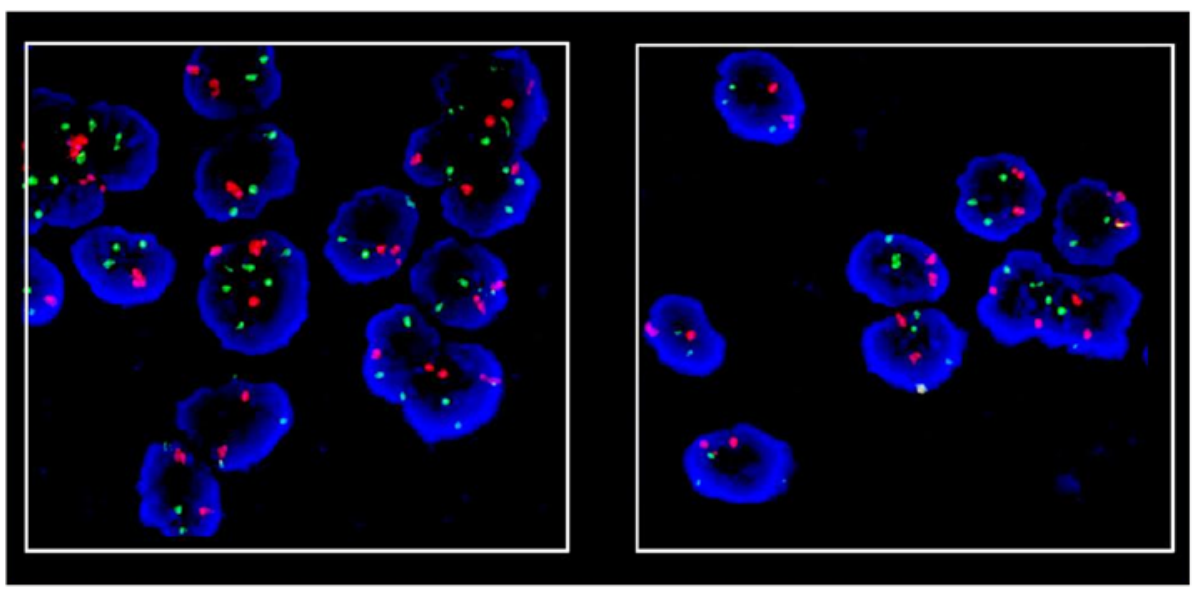

Figure 1. Representative image of FISH analysis in human uveal melanoma. Nuclei were stained with blue fluorescent DAPI. Specific signals for chromosome 3 are indicated in red; chromosome 4-specific signals are indicated in green.

Fluorescence microscopy. Slides were evaluated using a fluorescence microscope (Axio Imager Z2; Zeiss, Oberkochen, Germany). Image capture was performed by a monochrome charge-coupled device camera attached to the fluorescence microscope and ISIS software (MetaSystems, Altlussheim, Germany).

FISH analysis. Numerical aberrations of chromosome 3 and 4 were assessed by analyzing chromosome copy number on the basis of 100 relevant tumor cell nuclei. CI values for chromosome 3 and 4 were determined for the ratio of the whole FISH signal in the sample and the number of nuclei. Chromosome loss was stated as $<1.75$, polysomy was stated as $>2.25$ chromosome copy numbers/nucleus. 'Dominant' cell population value was determined. A cell population with a certain chromosome copy number was considered as 'dominant' cell population where the cut-off limit was $15 \%$ (26).

Statistical analysis. Indices for chromosome 3 and 4 were analyzed from the UM samples. The two datasets were evaluated using D'Agostino-Pearson omnibus normality test, and then Spearman correlation analysis was performed. Chromosome results, receptor findings and clinicopathological data were also analyzed. Statistical analysis was carried out with the use of GraphPad Prism 6.03 (GraphPad, San Diego, CA, USA).

Survival in the groups was plotted against the postoperative days (elapsed until death or the end of the follow-up period), according to the Kaplan-Meier method. Differences among the groups were investigated by means of Mantel-Cox log-rank and Gehan-Breslow-Wilcoxon tests. Statistical analysis was carried out with GraphPad Prism 6.03 software.

\section{Results}

Distribution of chromosome 3. Based on CI values, monosomy of chromosome 3 was found in 16 (35\%) samples. In 6 specimens (13\%), >2 copies of chromosome 3 were found. Normal biparental disomy was observed in 24 samples (52\%). In 26 samples one signal/cell/'dominant' cell population could be detected, whereas in 9 cases, clones containing 3 or more chromosome/nucleus were found. In 2 specimens, either loss of chromosome or polysomy were observed. Normal distribution of chromosome 3 was detected in 13 cases. In addition, the normal tissue samples contained negligible abnormal cell population $(<15 \%)$ (Table II). Representative distribution of chromosome 3 is shown in Fig. 1.

Distribution of chromosome 4. Based on the CI values, chromosome 4 could be detected in normal biparental disomy in 14 samples (30\%), while 32 cases $(70 \%)$ showed $>2$ signals/nucleus. In 8 samples one signal/cell/'dominant' cell population was observed, whereas in 41 cases, clones containing 3 or more chromosome/nucleus were found. In 6 specimens either loss of chromosome or polysomy was observed. Normal distribution of chromosome 4 was detected only in 3 cases (Table III). Representative distribution of chromosome 4 is shown in Fig. 1.

Statistical results. According to the statistical analysis, there was (Spearman $\mathrm{r}=0.42 ; 0.139-0.639 ; \mathrm{CI}, 0.95 \%$ ) a statistically significant $(\mathrm{p}<0.05)$ correlation between the copy number of chromosome 3 and 4 (Fig. 2). CI values for chromosomes 3 and 4 were determined for the samples and were considered to be normal (N, 1.75-2.25) or pathological ( $\mathrm{P},<1.75$ or $>2.25)$. Comparing the survival rate of the 4 groups (NN, NP, PN and PP), an obvious difference was revealed, however statistically significant differences could not be shown ( $\mathrm{p}=0.38$ for the Mantel-Cox test, and $\mathrm{p}=0.43$ for the Gehan-Breslow-Wilcoxon test). Even the 2 major groups $(\mathrm{N}$ and $\mathrm{P})$ were not found to be significantly different $(\mathrm{p}=0.12$ by both the Mantel-Cox and Gehan-Breslow-Wilcoxon tests), in spite of the considerable difference between their survival curves (Fig. 3). The correlation of aberrations in chromosome 3 and 4 with LH-RH-R findings was also investigated in $17 \mathrm{UM}$ samples where receptor data were available (24). No significant correlation was found among chromosome expression and LH-RH-R incidence and binding characteristics. Furthermore based on our findings and the clinicopathological data, no correlation was observed between clinical outcome and chromosome 3 and 4 status (data not shown). 
Table II. Distribution of chromosome 3 in the human uveal melanoma specimens.

\begin{tabular}{|c|c|c|c|c|c|c|c|c|c|c|c|}
\hline \multirow{3}{*}{$\begin{array}{l}\text { Sample } \\
\text { ID }\end{array}$} & \multicolumn{5}{|c|}{ Chromosome 3} & \multirow{3}{*}{$\begin{array}{l}\text { Sample } \\
\text { ID }\end{array}$} & \multicolumn{5}{|c|}{ Chromosome 4} \\
\hline & \multicolumn{2}{|c|}{$\begin{array}{l}\text { 'Dominant' cell } \\
\text { population } 1\end{array}$} & \multicolumn{2}{|c|}{$\begin{array}{c}\text { 'Dominant' cell } \\
\text { population } 2\end{array}$} & \multirow[b]{2}{*}{$\mathrm{CI}$} & & \multicolumn{2}{|c|}{$\begin{array}{c}\text { 'Dominant' cell } \\
\text { population } 1\end{array}$} & \multicolumn{2}{|c|}{$\begin{array}{c}\text { 'Dominant' cell } \\
\text { population } 2\end{array}$} & \multirow[b]{2}{*}{$\mathrm{CI}$} \\
\hline & Signals/cell & $\%$ & Signals/cell & $\%$ & & & Signals/cell & $\%$ & Signals/cell & $\%$ & \\
\hline 33 & 1 & 85 & & & 0.94 & 17 & 1 & 22 & & & 1.75 \\
\hline 23 & 1 & 94 & & & 1.06 & 37 & 1 & 44 & 3 & 24 & 1.80 \\
\hline 39 & 1 & 78 & & & 1.17 & 41 & 1 & 39 & 3 & 20 & 1.81 \\
\hline 30 & 1 & 77 & & & 1.23 & 16 & 1 & 15 & & & 1.91 \\
\hline 38 & 1 & 69 & & & 1.31 & 46 & 1 & 26 & 3 & 17 & 1.91 \\
\hline 35 & 1 & 71 & & & 1.33 & 23 & \multicolumn{4}{|c|}{ Normal } & 1.94 \\
\hline 42 & 1 & 66 & & & 1.35 & 36 & 1 & 23 & 3 & 24 & 2.04 \\
\hline 13 & 1 & 65 & & & 1.37 & 40 & 1 & 30 & 3 & 32 & 2.04 \\
\hline 19 & 1 & 64 & & & 1.37 & 24 & \multicolumn{4}{|c|}{ Normal } & 2.06 \\
\hline 37 & 1 & 62 & & & 1.40 & 25 & \multicolumn{4}{|c|}{ Normal } & 2.08 \\
\hline 41 & 1 & 62 & & & 1.41 & 38 & 1 & 20 & 3 & 28 & 2.10 \\
\hline 1 & 1 & 62 & & & 1.43 & 33 & 3 & 21 & & & 2.14 \\
\hline 10 & 1 & 60 & & & 1.48 & 28 & 1 & 16 & 3 & 21 & 2.21 \\
\hline 25 & 1 & 52 & & & 1.53 & 30 & 3 & 26 & & & 2.22 \\
\hline 32 & 1 & 39 & & & 1.66 & 42 & 3 & 36 & & & 2.26 \\
\hline 14 & 1 & 49 & & & 1.71 & 29 & 3 & 26 & & & 2.27 \\
\hline 43 & 1 & 25 & & & 1.76 & 43 & 3 & 38 & & & 2.28 \\
\hline 20 & 1 & 34 & & & 1.79 & 19 & 3 & 15 & & & 2.31 \\
\hline 46 & 1 & 23 & & & 1.84 & 39 & 3 & 44 & & & 2.33 \\
\hline 28 & 1 & 21 & & & 1.87 & 22 & 3 & 20 & & & 2.36 \\
\hline 29 & 1 & 19 & & & 1.88 & 35 & 3 & 32 & & & 2.37 \\
\hline 40 & 1 & 17 & & & 1.88 & 20 & 3 & 18 & & & 2.39 \\
\hline 44 & \multicolumn{4}{|c|}{ Normal } & 1.93 & 26 & & & $\geq 4$ & 18 & 2.48 \\
\hline 45 & \multicolumn{4}{|c|}{ Normal } & 1.93 & 27 & 3 & 25 & & & 2.48 \\
\hline 27 & 1 & 21 & & & 1.97 & 34 & 3 & 37 & & & 2.50 \\
\hline 24 & \multicolumn{4}{|c|}{ Normal } & 1.99 & 44 & 3 & 34 & & & 2.52 \\
\hline 2 & 1 & 35 & & & 2.00 & 12 & 3 & 20 & & & 2.53 \\
\hline 31 & \multicolumn{4}{|c|}{ Normal } & 2.01 & 32 & 3 & 42 & & & 2.55 \\
\hline 7 & \multicolumn{4}{|c|}{ Normal } & 2.04 & 2 & & & 3 & 16 & 2.65 \\
\hline 9 & & & nal & & 2.04 & 1 & & & $\geq 4$ & 30 & 2.72 \\
\hline 26 & & & & & 2.05 & 10 & 3 & 25 & $\geq 4$ & 22 & 2.79 \\
\hline 11 & & & & & 2.07 & 8 & 3 & 45 & & & 2.81 \\
\hline 17 & & & & & 2.07 & 31 & 3 & 48 & & & 2.82 \\
\hline 36 & 3 & 17 & & & 2.07 & 14 & 3 & 19 & $\geq 4$ & 33 & 2.94 \\
\hline 12 & 1 & 24 & 3 & 18 & 2.10 & 45 & 3 & 58 & $\geq 4$ & 21 & 2.99 \\
\hline 6 & & & & & 2.17 & 4 & 3 & 26 & $\geq 4$ & 26 & 3.00 \\
\hline 5 & & & & & 2.18 & 15 & 3 & 19 & $\geq 4$ & 39 & 3.03 \\
\hline 3 & & & & & 2.19 & 21 & 3 & 79 & & & 3.04 \\
\hline 8 & & & & & 2.21 & 6 & 3 & 28 & $\geq 4$ & 42 & 3.34 \\
\hline 34 & 3 & 21 & & & 2.22 & 3 & 3 & 27 & $\geq 4$ & 43 & 3.39 \\
\hline 21 & 3 & 19 & & & 2.26 & 11 & 3 & 28 & $\geq 4$ & 47 & 3.43 \\
\hline 18 & 1 & 42 & $\geq 4$ & 27 & 2.28 & 18 & 3 & 15 & $\geq 4$ & 24 & 3.43 \\
\hline 4 & & & 3 & 18 & 2.41 & 5 & 3 & 19 & $\geq 4$ & 72 & 3.94 \\
\hline 22 & 3 & 20 & & & 2.43 & 9 & & & $\geq 4$ & 81 & 3.94 \\
\hline 16 & 3 & 18 & $\geq 4$ & 18 & 2.53 & 7 & 3 & 22 & $\geq 4$ & 67 & 4.01 \\
\hline 15 & 3 & 29 & $\geq 4$ & 22 & 2.68 & 13 & & & $\geq 4$ & 91 & 5.39 \\
\hline $\begin{array}{l}\text { A cell por } \\
\text { sidered as } \\
\text { The samp }\end{array}$ & $\begin{array}{l}\text { pulation with a } \\
\text { 'dominant' cel } \\
\text { les are listed ac }\end{array}$ & $\begin{array}{l}\text { ertain } \\
\text { popul } \\
\text { ordin }\end{array}$ & $\begin{array}{l}\text { romosome cop } \\
\text { n where the cut } \\
\text { their chromos }\end{array}$ & $\begin{array}{l}\text { aumb } \\
\text { ff lim } \\
\text { le inc }\end{array}$ & $\begin{array}{l}\text { son- } \\
\text { s } 15 \% \text {. } \\
\text { CI). }\end{array}$ & $\begin{array}{l}\text { A cell po } \\
\text { sidered a } \\
\text { The sam } 1\end{array}$ & $\begin{array}{l}\text { pulation with a } \\
\text { 'dominant' cell } \\
\text { les are listed ac }\end{array}$ & $\begin{array}{l}\text { ertai } \\
\text { popu } \\
\text { ordir }\end{array}$ & $\begin{array}{l}\text { romosome cop } \\
\text { n where the cut } \\
\text { their chromoso }\end{array}$ & $\begin{array}{l}\text { numb } \\
\text { ff lim } \\
\text { ne ind }\end{array}$ & $\begin{array}{l}\text { as con- } \\
\text { s } 15 \% \text {. } \\
\text { I). }\end{array}$ \\
\hline
\end{tabular}

Table III. Distribution of chromosome 4 in the human uveal melanoma specimens. 


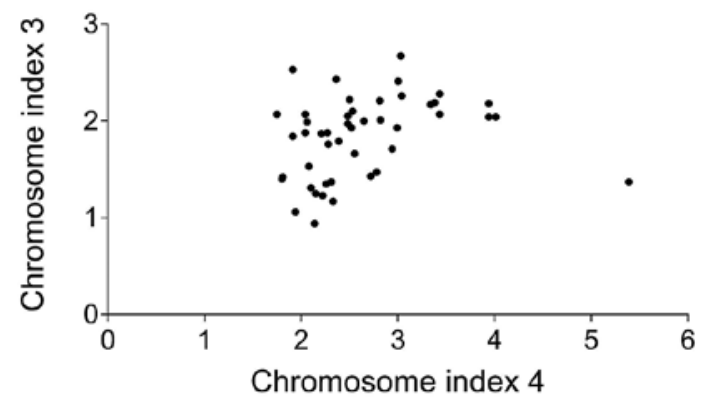

Figure 2. Correlation between the copy number of chromosome 3 and 4 in 46 human uveal melanoma specimens. A significant $(\mathrm{p}=0.0036)$ correlation was noted between the copy number of chromosome 3 and 4 (Spearman $\mathrm{r}=0.42 ; 0.139-0.639 ; \mathrm{CI}, 0.95 \%)$.
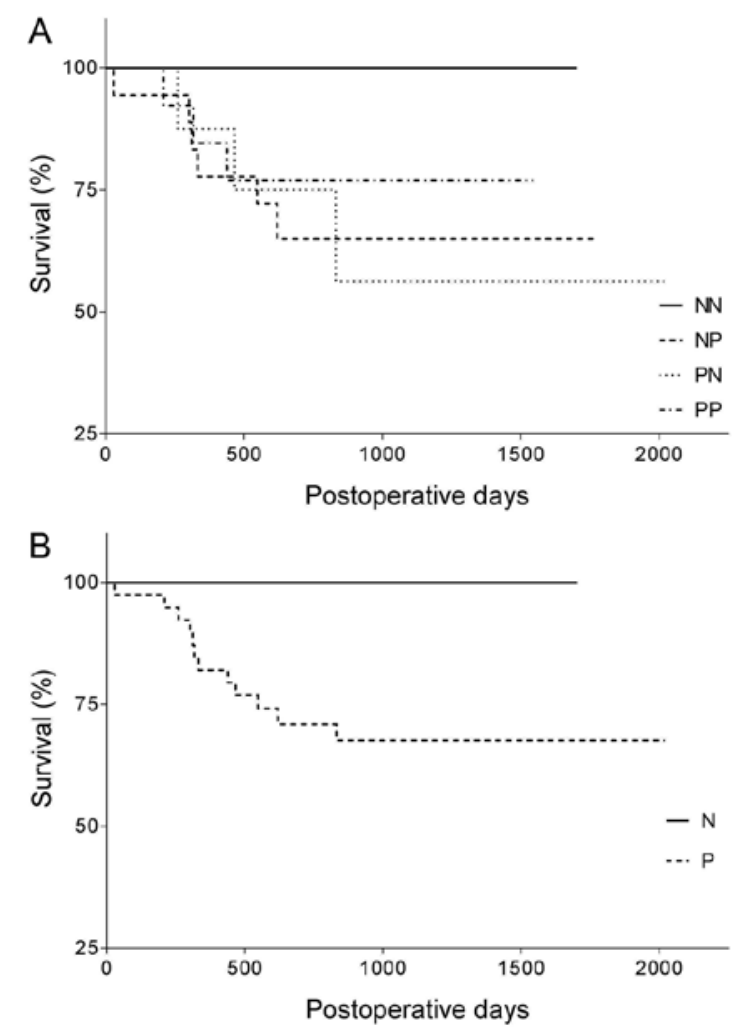

Figure 3. Kaplan-Meier survival curves of patients with uveal melanoma. (A) NN (normal CI3 and CI4), NP (normal CI3 pathological CI4), PN (pathological CI3 and normal CI4) and PP (pathological CI3 and CI4) status $(\mathrm{p}=0.38$ for the Mantel-Cox and $\mathrm{p}=0.43$ for the Gehan-Breslow-Wilcoxon tests). (B) N (including NN) and P (containing NP, PN and PP) status ( $\mathrm{p}=0.12$ for both the Mantel-Cox and Gehan-Breslow-Wilcoxon tests).

\section{Discussion}

Uveal melanoma (UM) is the most common form of primary ocular cancer in adults, with a mortality rate of $50 \%$ at 10-15 years after detection of the disease (27). Clinical treatment for the disease includes photocoagulation, radiotherapy, local tumor incision and eye removal. However, none of these treatments improves the survival rate noticeably (28). Adjuvant systemic therapy is mainly used in patients with high-risk of metastasis or in patients already presenting with metastasis, but the response rates to classical chemotherapeutic agents remain low (29). We previously demonstrated that LH-RH-R is expressed in approximately half (47\%) of human UMs (24). The effects of LH-RH and its analogs are mediated by high-affinity G-protein-coupled receptors for LH-RH located on the membranes of the pituitary gonadotrophs and different human types of cancers $(16,17,19-21)$. The presence of LH-RH-R in various types of cancers and cancer cell lines originating from organs other than those of the reproductive system has been shown in various studies $(14,16-19,21,30)$. Both agonists and antagonists of LH-RH may serve as potential therapeutic agents, acting directly on the target cancer cells (16,17,30-32). LH-RH agonists inhibit the gonadotropin secretion after continuous exposure (31). In contrast, antagonists of LH-RH produce a competitive blockade of LH-RH-R leading to an immediate cessation of the secretion of gonadotropins and sex steroids, reducing the time of the onset of therapeutic effects compared to the agonists (33). Agonistic analogs, such as triptorelin, leuprolelin, goserelin and buserelin are extensively applied in gynecology and oncology $(14,16-18,30)$. Potent antagonists of LH-RH, such as cetrorelix, ganirelix, abarelix and degarelix, have also been developed and are now available for clinical use $(14,16-18,30,33)$. The receptors for LH-RH on human tumors also serve as targets for LH-RH analogs linked to cytotoxic agents $(15-17,19,23,34)$. In the analog AN-152 (AEZS-108) doxorubicin (DOX) is covalently linked to the LH-RH agonist D-Lys ${ }^{6}-\mathrm{LH}-\mathrm{RH}$, that binds to the receptors present on the surface of breast, prostatic, ovarian and other cancer cells $(15-17,23,34)$. This analog has been extensively investigated in a large number of experimental studies (14-19,23,30,34), and also tested clinically in ovarian, endometrial, prostatic and bladder cancer. It is in clinical phase III trials on endometrial cancer (35). Generally, the genetic background of different cancers is extensively investigated. For example, aberrations of chromosome 4 have been demonstrated in cervical cancer, small cell lung cancer, glioblastoma and chronic lymphocytic leukemia (36-39). Chromosome 4 hyperploidy is the most prominent alteration found in Barrett's metaplasia and $89 \%$ of the patients display this aberration (40). Notably, the gene encoding LH-RH-R is located on chromosome $4 \mathrm{q} 21.2$. The numerical aberrations of chromosome 4 have never been studied in UM.

It was reported that monosomy 3 strongly predicts metastatic risk and other chromosomal abnormalities correlate with metastatic disease $(3,4)$. Monosomy 3 in choroidal melanoma is a significant predictor of metastasis-related death and has been associated with a $70 \%$ decrease in 5-year survival. Infrequently, abnormalities of other chromosomes such as losses of 1p, 6q, 9p, 10, 11q23-q25, and gain of chromosomes $6 \mathrm{p}, 7,8 \mathrm{q}$ and 10 have been reported $(3,11)$. Recently, several potential genes were proposed in UM, such as GNAQ,DDEF1, $N B S 1, H D M 2, B C L-2$ and $C C N D 1$; however, a significant role for most of these genes must be further investigated in tumorigenesis and progression towards metastasis must be confirmed $(41,42)$.

In the present study, one of our aims was to investigate the copy number of chromosome 3 due to the fact that it has been implicated in the aggressive behavior of UM. More importantly, copy number of chromosome 4 was also studied in the same human UM specimens using fluorescence in situ hybridization (FISH). The correlation between LH-RH-R 
expression, clinicopathological findings and numerical aberrations of chromosome 3 and 4 was similarly analyzed.

FISH can detect chromosomal alterations that are consistent with a diagnosis of neoplasia. Several studies have shown that FISH has significantly higher sensitivity for the detection of tumor cells than conventional cytology (43-45). FISH is also able to detect various types of cytogenetic alterations including aneusomy, duplication, amplification, deletion and translocation (8). In general, 3 basic types of DNA probes are used: centromeric (chromosome enumeration probes), whole chromosome (whole chromosome paints) and locus-specific probes (46).

We demonstrated in the present study, for the first time, that chromosome 4 is present in an abnormal copy number in the majority of UMs. Based on the chromosome index (CI) values, in $70 \%$ of samples of chromosome 4 , more than 2 signals/nucleus were detected while the normal 2 copies were found only in $30 \%$ of the cases. The monosomy of chromosome 3 was detected in $35 \%$ of the samples while in $13 \%$ of the cases polysomy was observed. Our results are somewhat different from previous studies concerning the frequency of the monosomy of chromosome 3 (50\%) (47-50). This slight difference may be partially explained by the possibly diverse genetic background of the Hungarian population.

In case of chromosome 3 , based on 'dominant' cell population values, one signal/cell/'dominant' cell population was observed in 26 samples whereas we found clones containing 3 or more chromosomes/nucleus in 9 cases. In 2 specimens either loss of the chromosome or polysomy was observed.

In the case of chromosome 4, one signal/cell/'dominant' was observed in 8 samples whereas in 41 cases clones containing 3 or more chromosomes/nucleus were detected. In 6 specimens either loss of the chromosome or polysomy was observed.

According to our statistical analysis, there is a moderate, statistically significant correlation between the copy numbers of chromosome 3 and 4 , but no correlation was found with LH-RH-R expression and chromosome aberrations.

We also determined the survival rate of the UM patients according to their CI. Comparison of the survival rate of the 4 groups (NN, NP, PN and PP) and the 2 major groups (N and $\mathrm{P}$ ), a moderate difference was revealed, although statistically significant differences could not be proven in spite of the considerable difference between their survival curves. As mentioned above, the diverse genetic background of the Hungarian population as well as the limited number of human UM specimens may have contributed to the limitation of the present study. Our research is in the early phase of the investigation of chromosome 4 status; therefore, multivariate statistical analysis may not be a proper statistical test at this moment. However, investigation of a larger population may be important which may indeed require a more powerful statistical test, such as multivariate statistical analysis. In conclusion, our results provide new informations concerning the genetic background of UM and may lead to a more precise prognosis and novel therapeutic approaches for cancer of the eye.

\section{Acknowledgements}

The present study was supported by the Hungarian Scientific Research Fund (OTKA) K 81596 (to G.H.),
TAMOP 4.2.2.A-11/1/KONV-2012-0025 Project (to G.H.), TAMOP-4.2.2/B-10/1-2010-0024 (to E.S), and the Gedeon Richter's Talentum Foundation (to E.S.). The present study was co-financed by the European Union and the European Social Fund. The present study is dedicated to the late Dr Andrea Treszl who recently died from metastatic breast cancer. Her intellectual, spiritual and personal contributions provided a great inspiration for our research on UM. We thank Dr Rudolf Gesztelyi for his excellent assistance in the statistical part of the present study.

\section{References}

1. Perry JD and Singh AD: Uveal melanoma: Epidemiologic aspects. Clin Ophthalmic Oncol: 75-87, 2014.

2. Mooy CM and De Jong PT: Prognostic parameters in uveal melanoma: A review. Surv Ophthalmol 41: 215-228, 1996.

3. Dopierala J, Damato BE, Lake SL, Taktak AFG and Coupland SE: Genetic heterogeneity in uveal melanoma assessed by multiplex ligation-dependent probe amplification. Invest Ophthalmol Vis Sci 51: 4898-4905, 2010.

4. Mensink HW, Vaarwater J, Kiliç E, Naus NC, Mooy N, Luyten G, Brüggenwirth HT, Paridaens D and de Klein A: Chromosome 3 intratumor heterogeneity in uveal melanoma. Invest Ophthalmol Vis Sci 50: 500-504, 2009.

5. Damato B: Does ocular treatment of uveal melanoma influence survival? Br J Cancer 103: 285-290, 2010.

6. Abildgaard SKO and Vorum H: Proteomics of uveal melanoma: A minireview. J Oncol 2013: 820953, 2013.

7. Hughes S, Damato BE, Giddings I, Hiscott PS, Humphreys J and Houlston RS: Microarray comparative genomic hybridisation analysis of intraocular uveal melanomas identifies distinctive imbalances associated with loss of chromosome $3 . \mathrm{Br} \mathrm{J}$ Cancer 93: 1191-1196, 2005.

8. Kilic E, van Gils W, Lodder E, Beverloo HB, van Til ME, Mooy CM, Paridaens D, de Klein A and Luyten GP: Clinical and cytogenetic analyses in uveal melanoma. Invest Ophthalmol Vis Sci 47: 3703-3707, 2006.

9. Onken MD, Worley LA and Harbour JW: A metastasis modifier locus on human chromosome $8 \mathrm{p}$ in uveal melanoma identified by integrative genomic analysis. Clin Cancer Res 14: 3737-3745, 2008.

10. Häusler T, Stang A, Anastassiou G, Jöckel KH, Mrzyk S, Horsthemke B, Lohmann DR and Zeschnigk M: Loss of heterozygosity of $1 \mathrm{p}$ in uveal melanomas with monosomy 3. Int $\mathrm{J}$ Cancer 116: 909-913, 2005.

11. van den Bosch T, Kilic E, Paridaens D and de Klein A: Genetics of uveal melanoma and cutaneous melanoma: Two of a kind? Dermatol Res Pract 2010: 360136, 2010.

12. Onken MD, Worley LA, Ehlers JP and Harbour JW: Gene expression profiling in uveal melanoma reveals two molecular classes and predicts metastatic death. Cancer Res 64: 7205-7209, 2004.

13. Ehlers JP, Worley L, Onken MD and Harbour JW: Integrative genomic analysis of aneuploidy in uveal melanoma. Clin Cancer Res 14: 115-122, 2008.

14. Schally AV: Luteinizing hormone-releasing hormone analogs: Their impact on the control of tumorigenesis. Peptides 20: 1247-1262, 1999.

15. Schally AV and Nagy A: Chemotherapy targeted to cancers through tumoral hormone receptors. Trends Endocrinol Metab 15: 300-310, 2004.

16. Schally AV and Halmos G: Targeting to Peptide Receptors. In: Drug Delivery in Oncology. Felix K, Peter S and Henning S (eds). Wiley-VCH, Weinheim, pp1219-1261, 2012.

17. Schally AV, Comaru-Schally AM, Nagy A, Kovacs M, Szepeshazi K, Plonowski A, Varga JL and Halmos G: Hypothalamic hormones and cancer. Front Neuroendocrinol 22: 248-291, 2001.

18. Schally AV, Szepeshazi K, Nagy A, Comaru-Schally AM and Halmos G: New approaches to therapy of cancers of the stomach, colon and pancreas based on peptide analogs. Cell Mol Life Sci 61: 1042-1068, 2004.

19. Szepeshazi K, Schally AV and Halmos G: LH-RH receptors in human colorectal cancers: Unexpected molecular targets for experimental therapy. Int J Oncol 30: 1485-1492, 2007. 
20. Halmos G, Arencibia JM, Schally AV, Davis R and Bostwick DG: High incidence of receptors for luteinizing hormone-releasing hormone (LHRH) and LHRH receptor gene expression in human prostate cancers. J Urol 163: 623-629, 2000.

21. Moretti RM, Montagnani Marelli M, Van Groeninghen JC and Limonta P: Locally expressed LHRH receptors mediate the oncostatic and antimetastatic activity of LHRH agonists on melanoma cells. J Clin Endocrinol Metab 87: 3791-3797, 2002.

22. Liu SV, Schally AV, Hawes D, Xiong S, Fazli L, Gleave M, Cai J, Groshen S, Brands F, Engel J, et al: Expression of receptors for luteinizing hormone-releasing hormone (LH-RH) in prostate cancers following therapy with LH-RH agonists. Clin Cancer Res 16: 4675-4680, 2010.

23. Seitz S, Buchholz S, Schally AV, Weber F, KlinkhammerSchalke M, Inwald EC, Perez R, Rick FG, Szalontay L, Hohla F et al: Triple negative breast cancers express receptors for LHRH and are potential therapeutic targets for cytotoxic LHRH-analogs, AEZS 108 and AEZS 125. BMC Cancer 14: 847, 2014.

24. Treszl A, Steiber Z, Schally AV, Block NL, Dezso B, Olah G, Rozsa B, Fodor K, Buglyo A, Gardi J, et al: Substantial expression of luteinizing hormone-releasing hormone $(\mathrm{LHRH})$ receptor type I in human uveal melanoma. Oncotarget 4: 1721-1728, 2013.

25. Balázs M, Adám Z, Treszl A, Bégány A, Hunyadi J and Adány R: Chromosomal imbalances in primary and metastatic melanomas revealed by comparative genomic hybridization. Cytometry 46 : 222-232, 2001

26. Bonaldi L,MidenaE,Filippi B,TebaldiE,Marcato R,Parrozzani R and Amadori A: FISH analysis of chromosomes 3 and 6 on fine needle aspiration biopsy samples identifies distinct subgroups of uveal melanomas. J Cancer Res Clin Oncol 134: 1123-1127, 2008.

27. Kilic E, Naus NC, van Gils W, Klaver CC, van Til ME, Verbiest MM, Stijnen T, Mooy CM, Paridaens D, Beverloo HB, et al: Concurrent loss of chromosome arm $1 \mathrm{p}$ and chromosome 3 predicts a decreased disease-free survival in uveal melanoma patients. Invest Ophthalmol Vis Sci 46: 2253-2257, 2005.

28. Yang $C$ and Wei W: The miRNA expression profile of the uveal melanoma. Sci China Life Sci 54: 351-358, 2011.

29. Bedikian AY, Legha SS, Mavligit G, Carrasco CH, Khorana S, Plager C, Papadopoulos N and Benjamin RS: Treatment of uveal melanoma metastatic to the liver: a review of the M. D. Anderson Cancer Center experience and prognostic factors. Cancer 76: $1665-1670,1995$.

30. Engel JB and Schally AV: Drug Insight: Clinical use of agonists and antagonists of luteinizing-hormone-releasing hormone. Nat Clin Pract Endocrinol Metab 3: 157-167, 2007.

31. Kovacs M and Schally AV: Comparison of mechanisms of action of luteinizing hormone-releasing hormone (LHRH) antagonist cetrorelix and LHRH agonist triptorelin on the gene expression of pituitary LHRH receptors in rats. Proc Natl Acad Sci USA 98 12197-12202, 2001.

32. Tolkach Y, Joniau S and Van Poppel H: Luteinizing hormonereleasing hormone (LHRH) receptor agonists vs antagonists: A matter of the receptors? BJU Int 111: 1021-1030, 2013.

33. Kovacs M, Schally AV, Csernus B and Rekasi Z: Luteinizing hormone-releasing hormone (LH-RH) antagonist Cetrorelix down-regulates the mRNA expression of pituitary receptors for LH-RH by counteracting the stimulatory effect of endogenous LH-RH. Proc Natl Acad Sci USA 98: 1829-1834, 2001.

34. Keller G, Schally AV, Gaiser T, Nagy A, Baker B, Westphal G, Halmos G and Engel JB: Human malignant melanomas express receptors for luteinizing hormone releasing hormone allowing targeted therapy with cytotoxic luteinizing hormone releasing hormone analogue. Cancer Res 65: 5857-5863, 2005.
35. Liu SV, Tsao-Wei DD, Xiong S, Groshen S, Dorff TB, Quinn DI, Tai YC, Engel J, Hawes D, Schally AV, et al: Phase I, dose-escalation study of the targeted cytotoxic LHRH analog AEZS-108 in patients with castration- and taxane-resistant prostate cancer. Clin Cancer Res 20: 6277-6283, 2014

36. Singh RK, Indra D, Mitra S, Mondal RK, Basu PS, Roy A, Roychowdhury S and Panda CK: Deletions in chromosome 4 differentially associated with the development of cervical cancer: Evidence of slit2 as a candidate tumor suppressor gene. Hum Genet 122: 71-81, 2007.

37. Shivapurkar N, Virmani AK, Wistuba II, Milchgrub S, Mackay B, Minna JD and Gazdar AF: Deletions of chromosome 4 at multiple sites are frequent in malignant mesothelioma and small cell lung carcinoma. Clin Cancer Res 5: 17-23, 1999.

38. Burford A, Little SE, Jury A, Popov S, Laxton R, Doey L, Al-Sarraj S, Jürgensmeier JM and Jones C: Distinct phenotypic differences associated with differential amplification of receptor tyrosine kinase genes at 4q12 in glioblastoma. PLoS One 8: e71777, 2013

39. Geller MD, Pei Y, Spurgeon SE, Durum C and Leeborg NJ: Chronic lymphocytic leukemia with a FGFR3 translocation: Case report and literature review of an uncommon cytogenetic event. Cancer Genet 207: 340-343, 2014.

40. Doak SH, Jenkins GJ, Parry EM, D'Souza FR, Griffiths AP, Toffazal N, Shah V, Baxter JN and Parry JM: Chromosome 4 hyperploidy represents an early genetic aberration in premalignant Barrett's oesophagus. Gut 52: 623-628, 2003.

41. Landreville S, Agapova OA, Harbour JW and Manuscript A: Emerging insights into the molecular pathogenesis of uveal melanoma. Future Oncol 4: 629-636, 2008.

42. Bauer J, Kilic E, Vaarwater J, Bastian BC, Garbe C and de Klein A: Oncogenic GNAQ mutations are not correlated with disease-free survival in uveal melanoma. Br J Cancer 101: 813-815, 2009.

43. Halling KC and Kipp BR: Bladder cancer detection using FISH (UroVysion assay). Adv Anat Pathol 15: 279-286, 2008.

44. Coleman JF, Theil KS, Tubbs RR and Cook JR: Diagnostic yield of bone marrow and peripheral blood FISH panel testing in clinically suspected myelodysplastic syndromes and/or acute myeloid leukemia: A prospective analysis of 433 cases. Am J Clin Pathol 135: 915-920, 2011.

45. Göhring G, Giagounidis A, Büsche G, Hofmann W, Kreipe HH, Fenaux P, Hellström-Lindberg E and Schlegelberger B: Cytogenetic follow-up by karyotyping and fluorescence in situ hybridization: Implications for monitoring patients with myelodysplastic syndrome and deletion $5 \mathrm{q}$ treated with lenalidomide. Haematologica 96: 319-322, 2011.

46. Bishop R: Applications of fluorescence in situ hybridization (FISH) in detecting genetic aberrations of medical significance. Biosci Horiz 3: 85-95, 2010.

47. Horsman DE, Sroka H, Rootman J and White VA: Monosomy 3 and isochromosome $8 \mathrm{q}$ in a uveal melanoma. Cancer Genet Cytogenet 45: 249-253, 1990.

48. Prescher G, Bornfeld N and Becher R: Nonrandom chromosomal abnormalities in primary uveal melanoma. J Natl Cancer Inst 82: $1765-1769,1990$.

49. Höglund M, Gisselsson D, Hansen GB, White VA, Säll T, Mitelman F and Horsman D: Dissecting karyotypic patterns in malignant melanomas: Temporal clustering of losses and gains in melanoma karyotypic evolution. Int J Cancer 108: 57-65, 2004.

50. Scholes AGM, Damato BE, Nunn J, Hiscott P, Grierson I and Field JK: Monosomy 3 in uveal melanoma: Correlation with clinical and histologic predictors of survival. Invest Ophthalmol Vis Sci 44: 1008-1011, 2003. 